\title{
ROLA MARII KAZIMIERY W STOSUNKACH POLSKO-FRANCUSKICH W CZASACH PANOWANIA JANA III SOBIESKIEGO
}

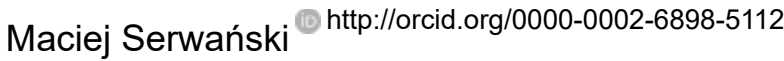 \\ Uniwersytet im. Adama Mickiewicza w Poznaniu
}

\section{ABSTRACT \\ THE IMPACT OF MARIE CASIMIRE ON THE POLISH-FRENCH RELATIONS IN THE REIGN OF JOHN III SOBIESKI}

\begin{abstract}
Queen Marie Casimire played an important role in the Polish-French relations. The article analyzes each stage of the political relationship between the two countries during Marie Casimire's stay in Poland. She played a significant, and largely decisive, role during the election of 1674 . The queen's influence was also an important factor in the making of the treaty of Jaworów. The friendly relationship between the Commonwealth and France changed in 1678 due to a combination of reasons. The Commonwealth reoriented her foreign policy to adopt an anti-French stance, as ultimately confirmed by the Treaty of the Holy League. It is also important to take note of the personalities and actions of the French ambassadors in Warsaw. The last one, Polignac, acted in cooperation with the queen towards reorienting the foreign policy and assuring an election of a proFrench candidate, but he was unsuccessful on both counts.
\end{abstract}

Keywords: John III Sobieski, France, Poland, foreign policy, diplomacy, Marie Casimire.

Słowa kluczowe: Jan III Sobieski, Francja, Polska, polityka zagraniczna, dyplomacja, Maria Kazimiera.

Zazwyczaj twierdzi się, że stosunki polsko-francuskie przepełnione były zawsze przyjaźnią, sympatią, a nawet serdecznością. W rzeczywistości pogląd ten odnosi się tylko do sfery kultury. Istniało bowiem w tej kwestii obopólne zainteresowanie. Francuzi w czasach nowożytnych byli, w różnych okolicznościach, zafascynowani sarmackimi obyczajami, strojami i sposobem zachowania panów polskich, na przykład podczas poselstwa Henryka Walezego w 1573 roku, a później w związku ze ślubem per procura i sprowadzeniem Ludwiki Marii Gonzagi de Nevers do Polski w 1645 
roku. Inaczej rzecz miała się w odniesieniu do spraw politycznych, także w czasach panowania Jana III. Nie da się poruszyć tego ostatniego tematu bez przedstawienia jego antecedensów.

Kluczową postacią, z punktu widzenia dwudziestodwuletniego panowania króla, była oczywiście Maria Kazimiera de la Grange d'Arquien, francuska małżonka Sobieskiego. Przypomnijmy, iż urodziła się ona w Nevers w 1641 roku i przybyła do Polski jako czterolatka w świcie Ludwiki Marii Gonzagi. Na dworze królowej polskiej przebywała dosyć krótko. W 1649 roku powróciła do rodzinnego gniazda w celu edukacji i dopiero w 1652 lub 1653 roku ponownie zawitała do Polski. Jej obecność na dworze Ludwiki Marii była znacząca. Dziewczynka była fille d'honneur, czyli dwórką królowej. Z uwagi na ten fakt królowa przemyśliwała o wydaniu jej za któregoś z magnatów koronnych lub litewskich, którzy jako „zięciowie dworu” mieli tworzyć - i tworzyli - stronnictwo profrancuskie. Mężowie ci byli zobowiązani do utrzymywania dobrych kontaktów z Francją i okazywania swojej lojalności królowi polskiemu i jego planom. Maria Kazimiera została w 1658 roku wydana za ordynata Jana Zamoyskiego zwanego Sobiepanem, wojewodę kijowskiego od 1658 roku a od 1659 roku wojewodę sandomierskiego. W 1659 roku, czyli rok po ślubie, Maria Kazimiera nawiązała romans z Janem Sobieskim, piastującym urząd chorążego koronnego. Znajomość ta zakończyła się tajnymi ślubami, uczynionymi w 1661 roku w kościele karmelitów w Warszawie, stanowiącymi wzajemną deklarację miłości. Zamoyski zmarł w 1665 roku z powodu syfilisu oraz hulaszczego trybu życia. Wówczas Sobieski i wojewodzina sandomierska zawarli oficjalny związek. Warunek stanowiło opowiedzenie się Sobieskiego po stronie dworu, choć $-\mathrm{z}$ tego, co wiemy - chorąży koronny nie był początkowo zainteresowany wzmacnianiem władzy królewskiej w Rzeczypospolitej. Wspomnijmy, iż szlachta zdecydowanie występowała przeciwko hasłom władzy absolutnej monarchy oraz reformatorskim dążeniom Ludwiki Marii, którą nazywano imperiosus mulier. Zaślubiny Jana Sobieskiego z Marią Kazimierą d'Arquien Zamoyską w 1665 roku zmusiły jednak chorążego koronnego (od 1665 roku marszałka wielkiego koronnego, a od 1666 roku hetmana polnego koronnego) do opowiedzenia się za przyjaźnią z Francją oraz wstąpienia do stronnictwa profrancuskiego na dworze polskim. Odtąd też Maria Kazimiera pojawiała się w polityce coraz częściej i ingerowała w bieg wydarzeń krajowych.

Już w okresie panowania Jana Kazimierza dochodziło z wyżej wymienionych powodów do buntów. W czasie rokoszu wznieconego przez Jerzego Sebastiana Lubomirskiego w latach 1665-1666 śpiewano taką piosenkę: „Bij Francuzów, bij, wziąwszy dobry kij! Wal Francuzów, wal, wbijaj ich na pal! Siecz Francuzów, siecz naostrzywszy miecz! Tnij Francuzów, tnij, to ich będzie mniej!". W takich okolicznościach polityka francuska musiała mierzyć się z polskimi realiami. Warto jednak zadać pytania, jak wyglądały kontakty z Francją oraz jakimi kanałami wymieniano informacje, na podstawie których budowano wzajemne wizerunki i stereotypy narodowe? Po pierwsze, wspólną przestrzeń kontaktów stanowiły podróże edukacyjne. Do tradycji edukacyjnej młodej szlachty należała podróż po Europie i prawie zawsze obejmowała ona Francję. Czasem wojaże przeistaczały się w studia na uczelniach w Paryżu, Lyonie lub w Orleanie. Innym razem przybierały postać podróży 
krajoznawczych. Drugim źródłem przepływu informacji były kontakty dyplomatyczne. Odbywały się podczas pobytów polskich poselstw w Paryżu oraz misji francuskich przedstawicieli w Rzeczypospolitej. Dodajmy, że strona francuska dwukrotnie mediowała w konfliktach polsko-szwedzkich, to jest w 1629 roku podczas zawarcia rozejmu w Altmarku (baron de Charnacé), a następnie w 1635 roku w czasie negocjacji w Sztumskiej Wsi (Klaudiusz de Mesmes, hrabia d'Avaux). Francuzi przyjeżdżali w towarzystwie sekretarzy i innych znawców dyplomacji. Poznawali Rzeczpospolitą, a jednocześnie Polacy mogli obserwować francuskie obyczaje. Trzecim źródłem kształtujących się poglądów był polski dwór królewski i jego ceremoniał, szczególnie po 1645 roku i przybyciu Ludwiki Marii jako małżonki Władysława IV. To właśnie ten ośrodek władzy wywarł przemożny wpływ na kształtowanie się wzorców i kultury francuskiej w Rzeczypospolitej, między innymi obyczajów związanych z modą $\mathrm{i}$ ingerencją kobiet w sprawy polityczne.

W 1667 roku zmarła Ludwika Maria Gonzaga de Nevers. Rolę rzeczniczki interesów politycznych Francji przejęła wtedy Maria Kazimiera. Sobieska posiadała wszystkie cechy charakteru swej protektorki, które wykorzystała do przeforsowania - już w czasach panowania Sobieskiego - reform ustrojowych w kwestii elekcji vivente rege oraz skarbowych, które kłóciły się ze szlacheckimi wolnościami i prawami. To właśnie w drugiej połowie XVII wieku rozgorzały antyfrancuskie nastroje w Rzeczypospolitej. Stronnictwo francuskie upadło wraz z abdykacją Jana Kazimierza we wrześniu 1668 roku. Okres panowania Michała Korybuta Wiśniowieckiego, ożenionego z Eleonorą Habsburżanką, był właściwie czasem prześladowania członków dawnego stronnictwa profrancuskiego, w tym samych Francuzów. Dodajmy, że poseł francuski Piotr de Bonzi był nękany i z czasem został zmuszony do opuszczenia kraju nad Wisłą.

Sytuacja odwróciła się wraz z elekcją Jana III Sobieskiego w maju 1674 roku. Francja nie popierała początkowo jego kandydatury, a wpływ na to miały zwycięstwa marszałka wielkiego koronnego nad Turcją. Ogromną rolę w przełamaniu niechęci strony francuskiej odegrała Maria Kazimiera, która już w styczniu 1674 roku nawiązała korespondencję z ambasadorem francuskim w Berlinie Louisem de Verjus. Sobieska w depeszach skarżyła się na bierność dyplomacji francuskiej w trakcie polskiego bezkrólewia oraz na to, że stronnictwo profrancuskie nie otrzymało jeszcze wskazówek co do decyzji Króla Słońce w sprawach polskich. Sobieska przekonywała ponadto przebywającego w Polsce dyplomatę Simona Arnaulda de Pomoponne'a, iż jej mąż oczekuje zgody monarchy francuskiego na władcę Rzeczypospolitej, prosi o poparcie i pieniądze potrzebne na kampanię. Maria Kazimiera wykreowała przed Ludwikiem XIV obraz stosunków panujących w Polsce, który niewiele miał wspólnego z rzeczywistością, i w ten sposób zaproponowała dworowi francuskiemu gotowość męża do objęcia tronu polskiego bez jego wiedzy.

Dopiero jednak w kwietniu 1674 roku przybył do Warszawy specjalny wysłannik króla Francji, biskup Marsylii Toussaint Forbin Janson, który niebawem spotka1 się z małżeństwem Sobieskich. Duchowny poinformował, że zgodnie z instrukcją jego zadaniem było zablokowanie kandydatury księcia lotaryńskiego i udzielenie poparcia Sobieskiemu, jednak w pierwszej kolejności zmuszony był poprzeć Jerzego 
Wilhelma Wittelsbacha z książąt na Neuburgu. W trakcie kolejnych spotkań przedstawiciel francuski dowiedział się, że notowania księcia Condé, jak i Wittelsbacha były niskie. Wówczas Maria Kazimiera, zapewne dnia 11 maja 1674 roku, całkiem przemyślanie zaproponowała kandydaturę męża, któremu przychylni byli wojsko i senatorowie. Działania te przyniosły skutek kilka dni później, kiedy duchowny przekazał hetmanowej 9000 liwrów na opłacenie głosów elekcyjnych. Fundusze te przesądziły o wygranej Sobieskiego dnia 21 maja 1674 roku i ogłoszeniu go królem Polski.

Nie zapominajmy, iż wielką rolę w tych francuskich kalkulacjach odgrywała bieżąca polityka w wymiarze europejskim. Francja, rywalizująca z Habsburgami i pozostająca $\mathrm{w}$ sojuszu z Turcją, dążyła do urealnienia koncepcji tak zwanej bariery wschodniej, czyli ustanowienia sojuszu przez Francję ze Szwecją, Rzecząpospolitą i Turcją celem maksymalnego ograniczenia władzy domu austriackiego na terenie Rzeszy. Burbonom zależało na przełamaniu dominacji rządów Habsburgów i sięgnięciu po elekcyjny tron cesarski. Nadzieje te nie były nowe, jeszcze w XVI wieku zgłaszano bowiem kandydatury Franciszka I oraz później Henryka II z Walezjuszów.

W początkach swojego panowania, pomimo związków ze stronnictwem francuskim, Jan III nie był gotowy zawrzeć aliansu z królem arcychrześcijańskim. Podobnie Ludwik XIV, z racji antytureckiej polityki króla i jego deklaracji odłożenia koronacji aż do czasu pokonania Imperium Otomańskiego, nie był zdecydowany podpisać sojuszu. Jan III Sobieski był jednak strategiem i człowiekiem myślącym pragmatycznie. Przewartościowanie na rzecz związania się z Francją wynikało z zagrożenia wywołanego zakusami elektora brandenburskiego Fryderyka Wilhelma, zwanego Wielkim Elektorem, inkorporacji Prus Książęcych. Inaczej wyglądały plany Sobieskiego, który pragnął wcielenia Prus Książęcych, a także Śląska do Korony i oddania ich we władanie któremuś ze swoich synów. Ogniwem łączącym idee polityczne Francji oraz plany terytorialne Jana III stała się znów Maria Kazimiera. Królowa zabiegała o poparcie pretensji męża, pomoc militarną i pieniężną. Ludwik XIV w dowód swych dobrych intencji nadesłał parze królewskiej liczne srebrne podarki, a Marię Kazimierę obiecał ,adoptować” i uznać księżniczką krwi. Latem 1675 roku ambasador francuski François de Béthune spostrzegł, iż tylko królowa Polski może nakłonić swego małżonka, ażeby doprowadził do końca zawarcie traktatu. Dyplomata nie zawiódł się w swych rachubach i już w czerwcu podczas spotkania monarchy z wysłannikami Francji podpisano tajny traktat w Jaworowie (11 czerwca 1675), uzupełniony w 1677 roku oddzielnym traktatem polsko-szwedzkim. Maria Kazimiera dziękowała potem Ludwikowi XIV nie tylko za okazaną pomoc, ale także za subsydia w wysokości 400000 dukatów (za cenę wywołania wojny z Brandenburgią i z Cesarstwem) oraz obdarzenie męża orderem Świętego Ducha, co jeszcze bardziej zbliżyło Sobieskich do francuskiego dworu.

Stan tak pomyślnych kontaktów trwał aż do 1678 roku, kiedy na horyzoncie zaczęło jawić się zagrożenie tureckie. Maria Kazimiera odczuwała coraz większe zmęczenie aliansem z Francją, tym bardziej że cele traktatu jaworowskiego nie zostały osiągnięte, a polityka bałtycka Sobieskiego poniosła zupełne fiasko. Do tego dochodziła obojętność dworu francuskiego wobec starań królowej Polski o przyznanie jej 
ojcu tytułu para i diuka Francji. Zaznaczmy jednak, że wojna z Republiką Zjednoczonych Prowincji odwróciła zainteresowanie króla francuskiego od spraw związanych z Rzecząpospolitą. Sobieski, rozczarowany brakiem poparcia ze strony Francji, już od około 1678 roku przemyśliwał o sojuszu z Habsburgami. Zawarł go jednak oficjalnie dopiero w 1683 roku. Można rzec, że na tym wydarzeniu zakończył się pierwszy etap profrancuskiej polityki króla. Jedynym zwornikiem łączącym dwór polski z Francją pozostała do pewnego stopnia Maria Kazimiera, zabiegająca o partykularne korzyści dla członków swej rodziny.

Sobieski, wstępując do Ligi Świętej w 1684 roku, całkowicie opowiedział się po stronie cesarskiej i eo ipso antyfrancuskiej. Nastąpił wówczas okres prześladowań członków stronnictwa profrancuskiego. Ofiarą machinacji padł na przełomie 1682 i 1683 roku podskarbi wielki koronny Jan Andrzej Morsztyn, który został oskarżony o uczestnictwo w spisku detronizacyjnym oraz o sprzeniewierzenie skarbu publicznego na osobiste cele. Był to symbol upadku stronnictwa profrancuskiego. Niezależnie od tego w Rzeczypospolitej działali znakomici francuscy posłowie. W latach 1676-1684 i 1684-1692 z misją zagraniczną przebywał w Polsce szwagier Sobieskiego François de Béthune. $Z$ kolei w roku wiktorii wiedeńskiej w nadzwyczajnych okolicznościach w Warszawie działał markiz François de Vitry. Po wyjeździe markiza de Béthune do Sztokholmu nad Wisłę przybył Vidame d'Esneval, który zmarł jeszcze w tym samym 1692 roku. Jego następca opat Bonportu Melchior de Polignac, przybyły rok później, zaznaczył się wyjątkową aktywnością na rzecz interesów francuskich. W 1693 roku schorowany król, w obliczu klęsk podczas wypraw mołdawskich (w 1686 i 1691 roku), skłonny był układać plany przyszłej elekcji. Polignac samodzielnie, bo bez oficjalnego poparcia ze strony Ludwika XIV, prowadził politykę zwrotu ku Francji. Jego działania opierały się na skaptowaniu stronników wśród elit politycznych. Do nich zaliczali się między innymi marszałek wielki koronny Stanisław Herakliusz Lubomirski, referendarz koronny i starosta warszawski Jan Dobrogost Krasiński oraz wojewoda sieradzki Jan Chryzostom Pieniążek herbu Odrowąż. Król Francji posiadał jednak odmienne plany. Tutaj ujawnia się kolejna cecha dyplomacji francuskiej w polityce polskiej, a właściwie jej wada: Francuzi byli przygotowani do przekupywania magnatów, wielmożów i wielkich panów, lecz nie do końca rozumieli mechanizm systemu klientalnego istniejącego w Rzeczypospolitej. Nie wystarczało bowiem trafić do magnaterii, ale należało także zwrócić się do drobnej i zbiedniałej szlachty, posiadającej swoje głosy na sejmikach i w trakcie elekcji królewskiej.

W czasach Polignaca nasiliła się współpraca gospodarcza pomiędzy Rzecząpospolitą a Francją. W początkach lat 90 . XVII wieku Francję dotknął poważny kryzys ekonomiczny, związany z nieurodzajem i toczonymi przez Ludwika XIV wojnami, co w niedługim czasie wywołało klęskę głodu. By zażegnać kłopoty, Król Słońce zdecydował się na zakup zboża w Polsce za pośrednictwem Gdańska. W lipcu 1693 roku ambasador Polignac pozyskał do tego pomysłu część patrycjatu gdańskiego. Sytuacja okazała się nagląca, ponieważ głód we Francji zaczął się szybko rozprzestrzeniać, a jeden z dyplomatów Ludwika XIV pisał nawet, iż tylko Polska może zaopatrzyć Francję w zboże. Informacja o trudnościach ekonomicznych we Francji 
szybko dotarła na dwór Jana III Sobieskiego. W tym samym czasie negocjowany był kontrakt małżeński jego córki Teresy Kunegundy z elektorem bawarskim Maksymilianem Emanuelem. Przedstawiciele bawarscy żądali wypłacenia posagu w wysokości 500000 talarów, co jak na owe czasy było sumą niebagatelną. Król godził się jedynie na 400000 talarów, przez co doszło do impasu w negocjacjach. W tej sytuacji ambasador Polignac zaoferował polskiemu monarsze transakcję polegającą na sprzedaży polskiego zboża za sumę brakujących królowi 100000 talarów. Niezależnie od tego już w listopadzie 1693 roku królowa zobowiązała się odsprzedać polskie zboże Francji i dostarczyć je do portów na zimę 1693 i wiosnę 1694 roku. Zboże z Gdańska miało popłynąć do Dunkierki i tam zostać rozładowane przez gdańskich szyprów. Trudności w pozyskaniu statków, jak i niesprzyjająca żegludze zima sprawiły, że transport został przesunięty na wiosnę.

Znakiem odradzających się stosunków polsko-francuskich były inne działania podjęte przez Marię Kazimierę, która w ostatnich latach panowania Sobieskiego objęła nieformalną pieczę nad sprawami politycznymi. Wyrazem samodzielności królowej było wynegocjowanie z królem Francji traktatu militarnego i handlowego we wrześniu 1692 roku. Sojusz Koron Północy przywracał relacje pomiędzy Paryżem, Kopenhagą, Sztokholmem i Warszawą. Przewidywał on pożyczkę francuską na rzecz utrzymania stronnictwa burbońskiego nad Wisłą oraz pomoc francuską na wypadek ataku na Rzeczpospolitą ze strony Brandenburgii, Rosji lub Cesarstwa. „Dyplomacja Marysieńki" napotkała jednak na zasadnicze trudności, Sobieski wymówił się bowiem od sygnowania traktatu, skrępowany przysięgą wobec członków Świętej Ligi.

Dnia 17 czerwca 1696 roku Jan III zmarł. Nastało bezkrólewie, zawsze interesujące dla państw obcych. Tym razem na polu elekcyjnym doszło do starcia kandydatur francuskiej, bawarskiej, brandenburskiej i saskiej. Pamiętać trzeba, że parę miesięcy przed śmiercią Sobieskiego do Francji przeniknęła wiadomość, iż Polignac, bez porozumienia z królem Ludwikiem XIV, popierał zabiegi Franciszka Ludwika de Bourbon-Conti. Pojawiło się w związku z tym pytanie, czy Ludwik XIV zgodzi się poprzeć swego własnego ambasadora w Rzeczypospolitej, czy też będzie upierać się przy jakimś innym rozwiązaniu. Conti posiadał wówczas swoich zwolenników wśród elit, głównie koronnych. Polignac pracował, tak jak kiedyś Jan de Monluc, przy elekcji Henryka Walezego, składając polskim szlachcicom obietnice w imieniu kandydata. Na polu elekcyjnym Conti wygrał, lecz - jak wiadomo - część szlachty niespodziewanie poparła zabiegi elektora saskiego Fryderyka Augusta I, przez co doszło do rozdwojonej elekcji. Na polskie wybrzeże przybyła flotylla francuska, lecz wobec oporu ze strony Gdańska zmuszona była stanąć na redzie w Oliwie, a w obliczu zaostrzających się kontaktów z władzami miasta musiała zawrócić. Upadek planów elekcyjnych księcia Conti spowodował zerwanie stosunków polsko-francuskich w XVII wieku. Był to także zmierzch pewnej konsekwentnej francuskiej polityki antyhabsburskiej w Rzeczypospolitej. Późniejszy traktat polsko-francuski z 1714 roku nie miał już w istocie żadnego znaczenia. Wraz z panowaniem Sobieskiego, a właściwie po jego śmierci, zakończyły się stałe relacje polsko-francuskie, które w sumie - ocenić możemy jako niezbyt dobre. 


\section{BIBLIOGRAFIA}

\section{Źródła}

Archiwum spraw zagranicznych francuskie do dziejów Jana Trzeciego, t. 1: lata 1674-1677;

t. 2: lata 1677-1679; t. 3: lata 1680-1683, wyd. K. Waliszewski, Kraków 1879-1884.

Mongrillon M. de, Pamiętnik sekretarza ambasady francuskiej w Polsce pod koniec panowania Jana III oraz w okresie bezkrólewia i wolnej elekcji po jego zgonie (1694-1698), z franc. przeł., oprac. i wstępem opatrzyła Ł. Częścik, Wrocław 1982.

Sarnecki K., Pamiętniki z czasów Jana Sobieskiego. Diariusz i relacje z lat 1691-1696, wyj. J. Woliński, t. 1-2, Wrocław 2004.

\section{Opracowania}

Berenger J., Dyplomacja francuska wobec tureckiego zagrożenia w 1683 r. [w:] Odsiecz Wiednia. Prace poświęcone trzechsetnej rocznicy zwycięstwa, „Acta Universitatis Lodziensis, Folia Historia", nr 26, s. 53-68.

Czarniecka A., Nikt nie stucha mnie za życia... Jan III Sobieski w walce z opozycyjna propaganda (1684-1696), Warszawa 2011.

Czermak W., Marya Kazimiera Sobieska, Kraków 1899.

Deiches E., Koniec Morstina. Studium historyczne z czasów Jana Sobieskiego, Kraków 1894.

Historia dyplomacji polskiej, t. 2: 1572-1795, red. Z. Wójcik, opr. J. Gierowski, J. Michalski, H. Wisner, Z. Wójcik, Warszawa 1982 (cz. 2: Dyplomacja polska w okresie wojen drugiej połowy XVII wieku (1648-1699), opr. Z. Wójcik, s. 163-330).

Kamieński A., Polska a Brandenburgia-Prusy $w$ drugiej połowie XVII wieku. Dzieje polityczne, Poznań 2002.

Kersten A., Maria Kazimiera de la Grange d'Arquien [w:] Polski słownik biograficzny, t. XIX, Kraków 1974, s. 637-644.

Kołodziej R., ,Ostatni wolności naszej klejnot”. Sejm Rzeczypospolitej za panowania Jana III Sobieskiego, Poznań 2014.

Komaszyński M., Jan III Sobieski a Battyk, Gdańsk 1983.

Komaszyński M., Księcia Contiego niefortunna wyprawa po koronę Sobieskiego, Warszawa 1971.

Komaszyński M., Maria Kazimiera d’Arquien Sobieska (1641-1716) królowa Polski, Kraków 1984.

Komaszyński M., Teresa Kunegunda Sobieska, Warszawa 1982.

Piwarski K., Dyplomacja polska w czasach Jana III Sobieskiego, „Polityka Narodów” 1933, z. 8, s. 13-55.

Piwarski K., Między Francją a Austrią. Z dziejów polityki Jana III Sobieskiego w latach 1687-1690, Kraków 1933.

Piwarski K., Osłabienie znaczenia międzynarodowego Rzeczypospolitej $w$ drugiej połowie XVII wieku, „Roczniki Historyczne” 1957, nr 23, s. 226-258. 
Serwański M., Être une reine étrangère: deux Françaises en Pologne [w:] Femmes et pouvoir politique. Les princesses d'Europe XVe-XVIIIe siècle, sous la direction d'Isabelle Poutrin et Marie-Karine Schaub, Rosny-sous-Bois 2007.

Serwański M., Jean III Sobieski et la Sainte-Ligue, „XVIIe Siècle” (Paris) 1998, R. 50, nr 199, z. 2, s. 277-290.

Serwański M., Ksztattowanie się stronnictwa profrancuskiego na dworze polskim $w$ wiekach XVI i XVII [w:] Dwór a kraj. Między centrum a peryferiami władzy, red. R. Skowron, Kraków 2003, s. 219-235.

Serwański M., La rivalité des factions à la cour de Pologne aux XVIe et XVIIe siècles [w:] Hofgesellschaft und Höflinge an europäischen Fürstenhöfen in der Frühen Neuzeit (15.18.Jh.). Société de Cour et courtisans dans Europe de l'époque moderne (XVe-XVIIIe siècle), herausgegeben von Klaus Malettke und Chantal Grell unter Mitwirkung von Petra Holz, Münster 2001, s. 217-230.

Serwański M., La victoire de Kahlenberg en 1683 et la conscience nationale des Polonais [w:] Exploration de la mémoire collective. Grands événements et mythes des origines. Actes du XIe colloque polono-français de l'Université Adam Mickiewicz de Poznan et de l'Université Marc Bloch de Strasbourg. Textes réunis par François-Xavier Cuche et Jean-Paul Schneider, Strasbourg 2004, s. 49-59.

Serwański M., Polityka Francji wobec Polski 1655-1660 [w:] Rzeczpospolita w latach potopu, red. J. Muszyńska, J. Wijaczka, Kielce 1996, s. 21-39.

Serwański M., Polska czasów Jana Sobieskiego [w:] L'Europa di Giovanni Sobieski. Cultura, politica, mercatura e società. Atti del VI Colloquio Internazionale (Viterbo 24 25 giugno 2004), a cura di Gaetano Platania, Viterbo 2005, s. 111-121.

Serwański M., Staropolskie tradycje kontaktów z Francją - związi serca czy rozsądku. Wykłady inauguracyjne Instytutu Historii Uniwersytetu im. Adama Mickiewicza, red. K. Ilski, Poznań 2009.

Skrzypietz A., Francuskie zabiegi o koronę polska po śmierci Jana III Sobieskiego, Katowice 2009.

Skrzypietz A., Królewscy synowie - Jakub, Aleksander i Konstanty Sobiescy, Katowice 2011.

Skrzypietz A., Melchior de Polignac i jego misja na dworze Jana III Sobieskiego [w:] Polska wobec konfliktów w Europie nowożytnej. Z dziejów dyplomacji i stosunków międzynarodowych w XV-XVIII wieku, red. R. Skowron, Kraków 2009, s. 421-443.

Skrzypietz A., Rozkwit i upadek rodu Sobieskich, Warszawa 2014.

Targosz K., Dwór królowej Marysieńki Sobieskiej ogniskiem recepcji teatru francuskiego, „Barok. Historia - Literatura - Sztuka” 1995, 2, nr 1, s. 43-74.

Targosz K., Polsko-francuskie zwiąki teatralne w XVII w., „Pamiętnik Teatralny” 1971, nr 20, s. 43-50.

Verneret H., Marie de La Grange d'Arquien (1641-1716). Une nivernaise règne sur Varsovie et Rome, Paris 1997.

Waliszewski K., Marysieńka. Marie de la Grange d'Arquien Reine de Pologne femme de Sobieski 1641-1716, Paris 1898.

Woliński J., Z dziejów wojny i polityki w dobie Jana Sobieskiego, Warszawa 1960.

Wójcik Z., Jan Sobieski 1629-1696, Warszawa 1983. 